\title{
PENGARUH PENERAPAN ELECTRONIC GOVERNMENT TERHADAP KUALITAS PELAYANAN PUBLIK PADA DINAS KEPENDUDUKAN DAN CATATAN SIPIL KABUPATEN KERINCI
}

\author{
ELIYUSNADI, S.Kom., M.Si., DPT \\ Dosen Sekolah Tinggi Ilmu Administrasi Nusantara Sakti (STIA_NUSA) \\ Sungai Penuh-Kerinci \\ www.eliyusnadistia@gmail.com
}

"This study aims to determine the effect of the application of electronic government on the quality of Dinas Kependudukan dan Catatan Sipil Kabupaten Kerinci. The formulation of the problem proposed is: Is there an Effect of the Application of Electronic Government on the Quality of Public Services in the Kerinci Regency Population and Civil Registry Office? How big is the effect of the application of electronic government on the quality of public services?. Where the research results are based on the analysis of the independent variable Application of Electronic Government to the Quality of Public Services, where the value of $t$ arithmetic is 0.960 with a significance level of 0.344>0.05\% or $t$ arithmetic $0.960<t$ table 2.733, then Ho is rejected Ha is accepted which means the Application of Electronic Government has no significant effect on the Quality of Public Services. Furthermore, based on the coefficient table it is known that the influence of Electronic Government on Service Quality is 0.085. Based on the analysis of the Electronic Government independent variable above it is known that the $R$ Square value of 0.085 which means that the influence between Electronic Government, Against Quality of Service is $8.5 \%$.

\section{Keywords: Government Electronict, Service Quality}

\section{PENDAHULUAN}

Penyelenggara kegiatan pelayanan di bidang administrasi kependudukan dan Pencatatan Sipil, Sebagaimana dijelaskan dalam Undang-Undang Nomor 24 Tahun 2013 bahwa instansi pelaksana adalah perangkat pemerintah kabupaten/kota yang bertanggung jawab dan berwenang melaksanakan pelayanan dalam urusan administrasi kependudukan, salah satunya yaitu Dinas Kependudukan dan Pencatatan Sipil (Disdukcapil) Kabupaten Kerinci.

Dinas Kependudukan dan Pencatatan Sipil Kabupaten Kerinci merupakan instansi yang melayani administrasi kependudukan, diantaranya adalah pembuatan akta kelahiran, akta kematian, akta pengakuan dan pengesahan anak, akta perkawinan dan perceraian bagi warga non muslim, pembuatan kartu keluarga, pembuatan surat pindah datang antar kabupaten/kota atau antar provinsi, serta pembuatan Kartu Tanda Penduduk (KTP) yang saat ini menjadi Kartu Tanda Penduduk Elektronik (KTP-el). 
Sebelumnya Kartu Tanda Penduduk Elektronik dikenal dengan dengan nama Electronict Kartu Tanda Penduduk (KTP-el). Perekaman Electronic Kartu Tanda Penduduk (KTP-el) dilakukan secara massal pada tahun 2012 disetiap kecamatan di daerah kemudian dicetak langsung oleh pemerintah pusat yang nantinya didistribusikan melalui pos ke masing-masing kecamatan untuk dibagikan kepada masyarakat secara langsung melalui Dinas Kependudukan dan Pencatatan Sipil, Electronict Kartu Tanda Penduduk (KTP-el) memiliki masa berlaku selama lima tahun. Namun setelah berlakunya KTP-el, maka KTP manual sudah tidak berlaku lagi terhitung Desember 2014.

Pada tahun 2013 ditetapkan Undang-Undang Nomor 24 Tahun 2013 tentang perubahan atas Undang-Undang Nomor 23 tahun 2006 tentang Administrasi Kependudukan. dalam Undang-Undang Nomor 23 tahun 2006 Electronict Kartu Tanda Penduduk (KTP-el) diubah nama menjadi Kartu Tanda Penduduk Elektronik (KTP-el) mengacu pada Ejaan Yang Disempurnakan (EYD) dalam bahasa indonesia. KTP-el untuk warga negara indonesia berlaku seumur hidup sedangkan untuk warga negara asing disesuaikan dengan masa ijin tinggal. selanjutnya KTPel yang sudah diterbitkan sebelum Undang-Undang Nomor 24 tahun 2013 yang dikenal sebagai Electronict Kartu Tanda Penduduk ditetapkan berlaku seumur hidup dan tidak perlu diperpanjang meski masa berlakunya telah berakhir. Sedangkan untuk pencetakan KTP-el tersebut saat ini dilayani oleh Dinas Kependudukan dan Pencatatan Sipil.

Mulai tanggal 31 Desember 2014 lalu, KTP manual sudah tidak diberlakukan lagi dan pembuatanya sudah tidak dilayani lagi oleh seluruh kantor kecamatan di seluruh Kabupaten di indonesia. Artinya semua penduduk yang telah berumur 17 tahun keatas wajib memiliki KTP-el. keadaan tersebut membuat Dinas Kependudukan dan Pencatatan Sipil didatangi puluhan hingga ratusan pemohon pembuatan KTP-el setiap harinya, hal ini juga terjadi di Dinas Kependudukan dan Pencatatan Sipil Kabupaten Kerinci.

Selain itu, Dinas Kependudukan dan Pencatatan Sipil Kabupaten Kerinci juga memiliki masalah keterbatasan sumber daya bahan pembuatan KTP-el yg jumlahnya terbatas karena beberapa masalah di pusat, salah satunya adalah adanya kasus korupsi pengadaan bahan yg dilakukan oleh Setya Novanto yang berimbas pada terbatasnya bahan pembuat KTP-el diseluruh indonesia khususnya di Dinas kependudukan dan Pencatatan Sipil di Kabupaten Kerinci. Dinas Kependudukan dan Pencatatan Sipil Kabupaten Kerinci juga memiliki masalah keterbatasan aparatur, dimana menurut Renstra Disdukcapil Kabupaten Kerinci tahun 20162021 hanya terdapat 35 orang PNS. jika dibandingkan dengan jumlah penduduk Kabupaten Kerinci dan banyaknya pelayanan yang dilakukan Dinas Kependudukan dan Pencatatan Sipil Kabupaten Kerinci maka bisa dikatakan tidak sebanding.

Disamping itu pelayanan KTP-el juga terkendala dengan kurangnya biaya untuk menjangkau wilayah-wilayah yang sulit dijangkau karena kendala sarana jalan yang tidak memungkinkan untuk dilalui. Salah satunya minimnya kendaraan operasional yang bisa dipergunakan untuk menjangkau wilayah seperti ini.

Sebagai penyelenggara pelayanan publik Dinas Kependudukan dan Pencatatan Sipil Kabupaten Kerinci dituntut untuk memberikan kualitas pelayanan 
yang terbaik, pelayanan yang efektif dan efisien demi kenyamanan publik. Salah satu pengukur kualitas pelayanan yaitu kepuasan masyarakat menurut Peraturan Menteri Pendayagunaan Aparatur Negara dan Reformasi Birokrasi Republik Indonesia Nomor 16 Tahun 2017.

\section{Tinjauan Pustaka}

\subsection{Pengertian Administrasi}

Menurut Fathoni (2006:10) Administrasi dapat di bedakan menjadi dua pengertian yaitu :

1. Administrasi dalam arti sempit, yaitu kegiatan ketatausahaan, yaitu berupa menerima, mencatat, mengadakan, mengirim, menghimpun, menyelenggarakan, kearsipan, dokumentasi menetapkan sistem kerja, mengadakan serta menjaga keharmonisan sistem kerja antara anggota organisasi.

2. Administrasi dalam arti luas yaitu, meliputi kegiatan - kegiatan sekelompok manusia, melalui tahap-tahap tertenti dan di pimpin secara efektif dan efisien dengan menggunkan sarana - sarana yang di butuh agar dapat tujuan yang di inginkan.

Sedangkan menurut Mc. Farlant (Handayaningrat, 2000:25) yang mengemukakan pendapatnya administrasi adalah suatu proses dan badan yang bertanggung jawab penentuan tujuan, di mana organisasi dan manajemen di gariskan. Sedangkan manajemen merupakan proses yang merealisasikan dari tujuan yang telah di tetapkan oleh organisasi sebelumnya.

Berdasarkan pengertian di atas, maka di kemukakan bahwa pada hakikatnya, administrasi adalah keseluruhan proses organisasi dalam bentuk kerja sama dua atau lebih dengan memanfaatkan sumber daya yang ada secara efektif dan efisien dengan menerapkan perencanaan, pengorganisasian, pemberian.

\subsection{Pengertian Manajemen Sumber Daya Manusia (MSDM)}

Keselarasan dalam mengelola SDM menjadi faktor utama kesuksesan jalannya sebuah organisasi. Lalu sumber daya yang bagaimana yang perlu dikembangkan agar tujuan organisasi bisa tercapai dengan baik.

Berikut ini adalah beberapa pengertian manajemen Sumber Daya Manusia (MSDM) menurut para ahli :

Manajemen Sumber Daya Manusia menurut Hasibuan (2003: 10), adalah ilmu dan seni mengatur hubungan dan peranan tenaga kerja agar efektif dan efisien membantu terwujudnya tujuan organisasi, karyawan dan masyarakat. Manajemen Sumber Daya Manusia adalah bidang manajemen yang khusus mempelajari hubungan dan peranan manajemen manusia dalam organisasi organisasi.

Manajemen Sumber Daya Manusia (MSDM) menurut Manullang (2004:198), adalah sebagai berikut : "Manajemen Sumber Daya Manusia adalah seni dan ilmu pengadaan, pengembangan dan pemanfaatan SDM sehingga tujuan organisasi dapat direalisasikan secara daya guna dan kegairahan kerja dari semua kerja". 
Manajemen Sumber Daya Manusia (MSDM) menurut Marwansyah (2010:3), manajemen sumber daya manusia dapat diartikan sebagai pendayagunaan sumber daya manusia di dalam organisasi, yang dilakukan melalui fungsi-fungsi perencanaan sumber daya manusia, rekrutmen dan seleksi, pengembangan sumber daya manusia, perencanaan dan pengembangan karir, pemberian kompensasi dan kesejahteraan, keselamatan dan kesehatan kerja, dan hubungan industrial.

Manajemen Sumber Daya Manusia (MSDM) menurut Sastrohadiwiryo (2002:22) menggunakan istilah manajemen tenaga kerja sebagai pengganti manajemen sumber daya manusia. Menurutnya, manajemen tenaga kerja merupakan pendayagunaan, pembinaan, pengaturan, pengurusan, pengembangan unsur tenaga kerja, baik yang berstatus sebagai buruh, karyawan, maupun pegawai dengan segala kegiatannya dalam usaha mencapai hasil guna dan daya guna yang sebesar-besarnya, sesuai dengan harapan usaha perorangan, badan usaha, organisasi, lembaga, maupun instansi.

Pengertian Manajemen Sumber Daya Manusia (MSDM) menurut Simamora (2000:11) MSDM adalah sebagai pendayagunaan, pengembangan, penilaian, pemberian balasan jasa dan pengelolaan terhadap individu anggota organisasi atau kelompok bekerja. MSDM juga menyangkut desain dan implementasi system perencanaan, penyusunan personalia, pengembangan karyawan, pengeloaan karir, evaluasi kerja, kompensasi karyawan dan hubungan perburuhan yang mulus.

Manajemen Sumber Daya Manusia menurut Dessler (2000: 2) adalah kebijakan dari praktik yang dibutuhkan seseorang untuk menjalankan aspek "orang" atau SDM dari posisi seorang manajemen, meliputi perekrutan, penyaringan, pelatihan, pengimbalan dan penilaian.

Manajemen Sumber Daya Manusia (MSDM) menurut Rivai (2003: 1), Manajemen Sumber Daya Manusia merupakan salah satu bidang dari manajemen umum yang meliputi segi-segi perencanaan, pengorganisasian, pelaksanaan dan pengendalian. Proses ini terdapat dalam fungsi atau bidang produksi, pemasaran, keuangan, maupun kepegawaian. Karena sumber daya manusia dianggap semakin penting perannya dalam pencapaian tujuan organisasi, maka berbagai pengalaman dan hasil penelitian dalam bidang SDM dikumpulkan secara sistematis dalam apa yang disebut manajemen sumber daya manusia. Istilah "manajemen" sempunyai arti sebagai kumpulan pengetahuan tentang bagaimana seharusnya memanage (mengelola) sumber daya manusia.

Manajemen Sumber Daya Manusia (MSDM) menurut Nawawi (2003:42), mengemukakan bahwa MSDM adalah : "Proses mendayagunakan manusia sebagai tenaga kerja secara manusiawi agar potensi fisik dan psikis yang dimiliki berfungsi maksimal bagi tercapainya tujuan organisasi”.

Manajemen Sumber Daya Manusia (MSDM) menurut Sutrisno (2009: 7) mempunyai definisi sebagai suatu perencanaan, pengorganisasian, pengarahan, dan pengawasan atas pengadaan, pengembangan, kompensasi, pengintegrasian, pemeliharaan, dan pemutusan hubungan kerja dengan maksud untuk mencapai tujuan organisasi organisasi secara terpadu. 
Manajemen Sumber Daya Manusia (MSDM) menurut Gomes (2002: 3), memberikan pengartian yang berbeda, bahwa MSDM adalah : "Suatu gerakan pengakuan terhadap pentingnya unsur manusia sebagai sumber daya yang cukup potensial yang perlu dikembangkan sedemikian rupa sehingga mampu memberikan kontribusi yang maksimal bagi organisasi dan bagi pengembangan dirinya”.

Manajemen Sumber Daya Manusia (MSDM) menurut Jackson (2006: 3) adalah rancangan sistem-sistem formal dalam sebuah organisasi untuk memastikan penggunaan bakat manusia secara efektif dan efisien guna mencapai tujuan organisasi.

\subsection{Pengertian Electronik Government}

Budi Rianto dkk (2012:36) menyimpulkan bahwa E-Government merupakan bentuk aplikasi pelaksanaan tugas dan tata laksana pemerintahan menggunakan teknologi telematika atau teknologi informasi dan komunikasi. Aplikasi E- Government memberikan peluang meningkatkan dan mengoptimalkan hubungan antar instansi pemerintah, hubungan antara pemerintah dengan dunia usaha dan masyarakat. Mekanisme hubungan itu melalui pemanfaatan teknologi informasi yang merupakan kolaborasi atau penggabungan antara komputer dan system jaringan komunikasi.

Budi Rianto dkk (2012:39) mengatakan sedikitnya ada empat indikator keberhasilan E-Government, yaitu :

1. Ketersediaan data dan informasi pada pusat data.

2. Ketersediaan data dan informasi bagi kebutuhan promosi daerah.

3. Ketersediaan aplikasi E-Government pendukung pekerjaan kantor dan pelayanan publik.

4. Ketersediaan aplikasi dialog public.

Selain itu, untuk melaksanakan maksud tersebut pengembangan $E$ government diarahkan untuk mencapai empat tujuan menurut Inpres RI No.3 Tahun 2003 tentang Kebijakan dan Strategi Nasional Pengembangan e-Government, yaitu

1. Pembentukan jaringan informasi dan transaksi pelayanan publik yang memiliki kualitas dan lingkup yang dapat memuaskan masyarakat luas serta dapat terjangkau di seluruh wilayah Indonesia pada setiap saat tidak dibatasi oleh sekat waktu dan dengan biaya yang terjangkau oleh masyarakat.

2. Pembentukan hubungan interaktif dengan dunia usaha untuk meningkatkan perkembangan perekonomian nasional dan memperkuat kemampuan menghadapi perubahan dan persaingan perdagangan internasional.

3. Pembentukan mekanisme dan saluran komunikasi dengan lembaga-lembaga negara serta penyediaan fasilitas dialog publik bagi masyarakat agar dapat berpartisipasi dalam perumusan kebijakan negara.

4. Pembentukan sistem manajemen dan proses kerja yang transparan dan efisien serta memperlancar transaksi dan layanan antar lembaga pemerintah dan pemerintah daerah otonom. 
Dalam Jurnal Administrasi Negara (2006:19) dijelaskan bahwa Egovernment merupakan pemanfaatan dan pendayagunaan teknologi komunikasi dan informasi sebagai indikator dalam rangka mencapai beberapa tujuan dan kebutuhan yaitu :

1. Meningkatkan efisiensi dan cost-efectiveness dari pemerintah;

2. Memberikan jasa pelayanan kepada masyarakat secara lebih baik;

3. Menyediakan akses informasi kepada publik secara lebih luas;

4. Menjadikan penyelenggaraan pemerintah lebih bertanggung jawab dan transparan kepada masyarakat.

Menurut Indrajit (2002:5) manfaat yang diperoleh dengan diterapkannya konsep e-Government bagi suatu negara, antara lain:

1. Memperbaiki kualitas pelayanan pemerintah kepada para stakeholder-nya (masyarakat, kalangan bisnis, dan industri) terutama dalam hal kinerja efektivitas dan efisiensi di berbagai bidang kehidupan bernegara.

2. Meningkatkan trasnparansi, kontrol, dan akuntabilitas penyelenggaraan pemerintah dalam rangka penerapan konsep Good Governance.

3. Mengurangi secara signifikan total biaya administrasi,relasi, dan interaksi yang dikeluarkan pemerintah maupun stakeholdernya untuk keperluan aktivitas sehari-hari.

4. Memberikan peluang bagi pemerintah untuk mendapatkan sumber-sumber pendapatan baru melalui interaksinya dengan pihak-pihak berkepentingan.

5. Menciptakan suatu lingkungan masyarakat baru yang dapat secara tepat menjawab berbagai permasalahan yang dihadapi sejalan dengan berbagai perubahan global dan trend yang ada.

6. Memberdayakan masyarakat dan pihak-pihak lain sebagai mitra pemerintah dalam proses pengambilan berbagai kebijakan publik secara merata dan demokratis.

Sedangkan menurut Tjahjanto dalam Salam (2004:254), manfaat terpenting dari implementasi e-Government adalah terwujudnya pemerintahan yang lebih bertanggung jawab (accountable) bagi warganya. Selain itu, akan lebih banyak masyarakat yang bisa mengakses informasi, pemerintahan juga lebih efisien dan efektif, serta akan tercipta layanan pemerintahan yang lebih sesuai dengan kebutuhan masyarakat. Diharapkan dengan pemanfaatan yang lebih baik atas sumber daya, proses dan teknologi informasi bisa terjadi pula pemerintahan yang lebih baik.

Penerapan E- Government Menurut Inpres No 3 Tahun 2003

a. Persiapan

1. Pembuatan situs Informasi disetiap lembaga

2. Penyiapan SDM

3. Penyiapan sarana akses

4. Sosialisasi Situs Informasi

b. Pematangan 
Pembuatan Situs Informasi public interaktif

c. Pementapan

1. Pembuatan Situs Transaksi pelayanan publik

2. Pembuatan interoperabilitas aplikasi maupun data dengan lembaga lain

d. Pemanfaatan

Government to Citizen

\subsection{Pelayanan Publik}

Undang-undang No.25 Tahun 2009 mendefinisikan pelayanan publik sebagai kegiatan atau rangkaian kegiatan dalam rangka pemenuhan kebutuhan pelayanan sesuai dengan peraturan perundang-undangan bagi setiap warga negara dan penduduk atas barang, jasa, dan/atau pelayanan administratif yang disediakan oleh penyelenggaraan pelayanan publik.

Pelayanan publik adalah kepercayaan publik. Warga negara berharap pelayanan publik dapat melayani dengan kejujuran dan pengelolaan sumber penghasilan secaratepat, dan dapat dipertanggung jawabkan kepada publik (Lewis dan Gilman, 2005:32).

Menurut pendapat para ahli tersebut dapat dilihat bahwa pelayanan publik adalah pelayanan yang berorientasi atau dilakukan untuk masyarakat secara umum, jadi siapapun berhak mendapatkan pelayanan yang baik jika memerlukan informasi dan jasa atau produk yang mereka inginkan.

\subsection{Kualitas Pelayanan Publik}

Menurut Moenir (2000:16) pelayanan adalah proses pemenuhan kebutuhan melalui aktivitas orang lain yang lain yang langsung, atau dengan kata lain pelayanan sebagai suatu proses intraksi antara orang lain dengan yang lainnya. Menurut Agung Kurniawan (dalam Pasalong, 2007:128) mengatakan bahwa pelayanan publik adalah pemberian pelayanan (melayani) keperluan orang lain atau masyarakat yang mempunyai kepentingan pada organisasi itu sesuai dengan aturan pokok dan tata cara yang telah ditetapkan. Kualitas menurut Fandy Tjiptono (2004:2), adalah kesesuaian dengan persyaratan/tuntutan, kecocokan pemakaian, perbaikan atau penyempurnaan keberlanjutan, bebas dari kerusakan, pemenuhan kebutuhan pelanggan semenjak awal dan setiap saat, melakukan segala sesuatu secara benar semenjak awal, sesuatu yang bisa membahagiakan pelanggan.

Berdasarkan UU No. 25 Tahun 2009 tentang Pelayanan Publik, standar pelayanan adalah: penyelenggara berkewajiban menyusun dan menetapkan standar pelayanan dengan memperhatikan kemampuan penyelenggara, kebutuhan masyarakat, dan kondisi lingkungan. Menurut Moenir (2002: 88) faktor-faktor yang mendukung pelayanan yaitu faktor kesadaran, faktor aturan, faktor organisasi, faktor pendapatan, faktor keterampilan tugas dan faktor Sarana.

Menurut Zeithaml, dan Berry dalam Saleh (2010:103) yang melakukan penelitian khusus terhadap beberapa jenis jasa dan berhasil mengidentifikasi sepuluh faktor utama yang menentukan kualitas jasa. Kesepuluh faktor tersebut adalah: 
1. Reliability, mencakup dua hal pokok, yaitu konsistensi kerja (performance) dan kemampuan untuk dipercaya (dependbility). Hal ini berarti organisasi memberikan jasanya secara tepat semenjak saat pertama. Selain itu juga berarti bahwa organisasi yang bersangkutan memenuhi janjinya, misalnya menyampaikan jasanya sesuai dengan jadwal yang disepakati.

2. Responsiveness, yaitu kemauan atau kesiapan para karyawan untuk memberikan jasa yang dibutuhkan pelanggan.

3. Competence, artinya setiap orang dalam suatu organisasi memiliki keterampilan dan pengetahuan yang dibutuhkan agar dapat memberikan jasa tertentu.

4. Accessibility, meliputi kemudahan untuk menghubungi dan ditemui. Hal ini berarti lokasi fasilitas jasa yang mudah dijangkau, waktu menunggu yang tidak terlalu lama, saluran komunikasi organisasi mudah dihubungi, dan lain-lain.

5. Courtesy, meliputi sikap sopan santun, respek, perhatian, dan keramahan yang dimiliki para kontak personal.

6. Communication, artinya memberikan informasi kepada pelanggan pada bahasa yang dapat mereka pahami, serta selalu mendengarkan saran dan keluhan pelanggan.

7. Credibility, yaitu sifat jujur dan dapat dipercaya. Kredibilitas mecakup nama organisasi, reputasi organisasi, karakterisktik pribadi kontak personal, dan interaksi dengan pelanggan.

8. Security, yaitu aman dari bahaya, resiko, atau keragu-raguan. Aspek ini meliputi keamanan secara fisik (physical safety), keamanan finansial (financial security), dan kerahasiaan (confidentiality).

9. Understanding/Knowing the Customer, yaitu usaha untuk memahami kebutuhan pelanggan.

10. Tangibles, yaitu bukti fisik dari jasa, bisa berupa fasilitas fisik, peralatan yang dipergunakan, atau penampilan dari personil.

Perkembangan selanjutnya, Zheithalm et al dalam Ariani (2009:180) menyederhanakan sepuluh dimensi di atas menjadi lima dimensi pokok yang dikenal dengan SERQUAL (service quality) yang terdiri dari:

1. Bukti fisik (tangibles) yaitu kemampuan suatu organisasi dalam menunjukkan eksistensinya kepada pihak eksternal. Penampilan dan kemampuan sarana dan prasarana fisik organisasi yang dapat diandalkan serta keadaan lingkungan sekitarnya merupakan salah satu cara organisasi jasa dalam menyajikan kualitas layanan terhadap pelanggan. Diantaranya meliputi fasilitas fisik (gedung, buku, rak buku, meja dan kursi, dan sebagainya), teknologi (peralatan dan perlengkapan yang dipergunakan), serta penampilan pegawai.

2. Keandalan (reliability) adalah kemampuan organisasi memberikan pelayanan sesuai dengan apa yang dijanjikan secara akurat dan terpercaya. Kinerja harus sesuai dengan harapan pelanggan yang tercermin dari ketepatan waktu, pelayanan yang sama untuk semua pelanggan tanpa kesalahan, sikap simpatik dan akurasi yang tinggi. 
3. Daya tanggap (responsiveness) adalah kemauan untuk membantu pelanggan dan memberikan jasa dengan cepat dan tepat dengan penyampaian informasi yang jelas. Mengabaikan dan membiarkan pelanggan menunggu tanpa alasan yang jelas menyebabkan persepsi yang negative dalam kualitas pelayanan.

4. Jaminan (assurance) adalah pengetahuan, kesopan-santunan dan kemampuan para pegawai organisasi untuk menumbuhkan rasa percaya para pelanggan kepada organisasi. Hal ini meliputi beberapa komponen, antara lain:

a. Komunikasi (communication), yaitu secara terus menerus memberikan informasi kepada pelanggan dalam bahasa dan penggunaan kata yang jelas sehingga para pelanggan dapat dengan mudah mengerti apa yang diinformasikan pegawai serta dengan cepat dan tanggap menyikapi keluhan dan komplain dari para pelanggan.

b. Kredibilitas (credibility), perlunya jaminan atas suatu kepercayaan yang diberikan kepada pelanggan, believability atau sifat kejujuran, menanamkan kepercayaan, memberikan kredibilitas yang baik bagi organisasi pada masa yang akan datang.

c. Keamanan (security), adanya suatu kepercayaan yang tinggi dari pelanggan akan pelayanan yang diterima. Tentunya pelayanan yang diberikan mampu memberikan suatu jaminan kepercayaan.

d. Kompetensi (competence) yaitu keterampilan yang dimiliki dan dibutuhkan agar dalam memberikan pelayanan kepada pelanggan dapat dilaksanakan dengan optimal.

e. Sopan santun (courtesy), dalam pelayanan adanya suatu nilai moral yang dimiliki oleh organisasi dalam memberikan pelayanan kepada pelanggan. Jaminan akan kesopan-santunan yang ditawarkan kepada pelanggan sesuai dengan kondisi dan situasi yang ada.

5. Empati (empathy) yaitu memberikan perhatian yang tulus dan bersifat individual atau pribadi yang diberikan kepada pelanggan dengan berupaya memahami keinginan konsumen dimana suatu organisasi diharapkan memiliki suatu pengertian dan pengetahuan tentang pelanggan, memahami kebutuhan pelanggan secara spesifik, serta memiliki waktu pengoperasian yang nyaman bagi pelanggan.

\subsection{Ciri-ciri pelayanan yang baik}

Ciri-ciri pelayanan yang baik menurut Kasmir (2005:39) dirumuskan sebagai berikut:

1. Bertanggung jawab kepada setiap pelanggan/pengunjung sejak awal hingga selesai.

2. Mampu melayani secara cepat dan tepat.

3. Mampu berkomunikas.

4. Mampu memberikan jaminan kerahasiaan setiap transaksi.

5. Memiliki pengetahuan dan kemampuan yang baik.

6. Berusaha memahami kebutuhan pelanggan/pengunjung.

7. Mampu memberikan kepercayaan kepada pelanggan/pengunjung. 


\subsection{Faktor-Faktor Dominan yang Mempengaruhi Kualitas Pelayanan Publik}

Dari beberapa kajian, dapat diidentifikasi bahwa faktor-faktor yang mempengaruhi kualitas pelayanan publik, apabila dikelompokkan berdasarkan faktor-faktor yang ada, maka akan didapatkan beberapa faktor dominan yang mempengaruhi kualitas pelayanan publik. Faktor-faktor dominan tersebut adalah:

(1) Motivasi Kerja Birokrasi dan aparatur;

(2) Kemampuan aparatur;

(3) pengawasan/kontrol sosial;

(4) Perilaku birokrasi/aparatur;

(5) Komunikasi, disposisi dan struktur birokrasi serta iklim komunikasi organisasi dan aliran informasi;

(6) Restrukturisasi organisasi.

Masing-masing faktor mempengaruhi kualitas pelayanan publik. Artinya, secara umum dapat dikatakan bahwa keenam faktor tersebut secara dominan mempengaruhi kualitas pelayanan publik, di samping faktor-faktor lainnya.

\subsection{Kerangka Pemikiran}

Adapun pendapat ahli tentang Penerapan Electronik Government, dan Kualitas Pelayanan yang sekaligus penulis jadikan sebagai indikator dalam penelitian ini yaitu :

\section{A. Variabel Penerapan Electronik Government (X)}

Budi Rianto dkk (2012:39) mengatakan sedikitnya ada empat indikator keberhasilan E-Government, yaitu :

1. Ketersediaan data dan informasi pada pusat data.

2. Ketersediaan data dan informasi bagi kebutuhan promosi daerah.

3. Ketersediaan aplikasi E-Government pendukung pekerjaan kantor dan pelayanan publik.

4. Ketersediaan aplikasi dialog public.

\section{B. Variabel Kualitas Pelayanan (Y)}

Menurut Zeithhaml dkk (dalam pasalong, 2008:135), untuk mengetahui kualitas pelayanan yang dirasakan secara nyata oleh konsumen, ada indikator ukuran kepuasan konsumen yang terletak pada lima dimensi kualitas pelayanan menurut apa yang dikatakan konsumen. Lima dimensi servqual tersebut, yaitu:

1. Tangible (berwujud)

2. Reliabelity (kehandalan)

3. Responsiviness (ketanggapan)

4. Assurance (jaminan)

5. Emphaty (Empati).

Untuk lebih jelasnya dapat dilihat pada gambar 1.1. Kerangka penelitian berikut.

\section{Gambar 1.1.}




\section{Kerangka Penelitian}

\begin{tabular}{|ll|}
\hline \multicolumn{3}{|c|}{ Variabel Penerapan } \\
E-Government $(\mathrm{X})$ \\
\hline 1. & Ketersediaan data dan \\
informasi pada pusat data. \\
2. & Ketersediaan data dan \\
informasi bagi kebutuhan \\
KTP-el. \\
3. Ketersediaan aplikasi E- \\
Government pendukung \\
pekerjaan kantor dan \\
pelayanan publik. \\
4. Ketersediaan aplikasi \\
dialog public.
\end{tabular}

Sumber : Budi Rianto dkk (2012:39)
Variabel Kualitas Pelayanan (Y)
1. Tangible (berwujud)
2. Reliabelity (kehandalan)
3. Responsiviness (ketanggapan)
4. Assurance (jaminan)
5. Emphaty (Empati)

Sumber : Zeithhaml dkk (dalam pasalong, 2008:135) 


\subsection{Hipotesis}

Nasution (1996:38) menyatakan hipotesis adalah tiap pernyataan tentang suatu hal yang bersifat sementara yang belum dibuktikan kebenarannya secara empiris. Menurut Sugiyono (1994:39), mengatakan bahwa hipotesis merupakan jawaban sementara terhadap rumusan masalah penelitian yang belum dibuktikan kebenarannya secara nyata sehingga perlu diuji kebenarannya. Untuk memberi arah agar tujuan yang telah ditetapkan dapat tercapai maka hipotesis yang diajukan dalam penelitian ini adalah sebagai berikut :

Ho : r = 0, Tidak terdapat Pengaruh Penerapan Electronict Government Terhadap Kualitas Pelayanan Publik Pada Dinas Kependudukan dan Pencatatan Sipil Kabupaten Kerinci.

Ha $: \mathrm{r} \neq 0$, Terdapat Pengaruh Penerapan Electronict Government Terhadap Kualitas Pelayanan Publik Pada Dinas Kependudukan dan Pencatatan Sipil Kabupaten Kerinci.

\section{Metode Penelitian}

Untuk menganalisis Pengaruh Penerapan Electronict Government Terhadap Kualitas Pelayanan Publik Pada Dinas Kependudukan dan Pencatatan Sipil Kabupaten Kerinci dalam penelitian ini penulis menggunakan Pendekatan Kuantitatif yaitu merupakan penelitian yang dilakukan dengan melakukan perhitungan-perhitungan yang berkaitan dengan penempatan terhadap Kualitas Pelayanan.

\section{HASIL DAN PEMBAHASAN}

Berdasarkan data dari jawaban responden yang penulis dapatkan di lokasi penelitian, maka penulis melakukan pengolahan data yang sekaligus menjadi pembahasan dalam skripsi ini.

\subsection{Analisis Pengaruh Penerapan Electronict Government Terhadap Kualitas Pelayanan Publik}

Untuk mengetahui Pengaruh Penerapan Electronict Government Terhadap Kualitas Pelayanan Publik yaitu dengan menggunakan teknik analisis statistik regresi sederhana untuk variabel Penerapan Electronict Government Terhadap Kualitas Pelayanan Publik. Perhitungan Pengaruh Penerapan Electronict Government Terhadap Kualitas Pelayanan Publik dapat dilihat pada tabel berikut :

\section{Tabel 4.1}

Pengaruh Penerapan Electronict Government Terhadap Kualitas Pelayanan Publik 


\section{Coefficients $^{\mathrm{a}}$}

\begin{tabular}{|c|c|c|c|c|c|c|}
\hline & & \multicolumn{2}{|c|}{$\begin{array}{l}\text { Unstandardized } \\
\text { Coefficients }\end{array}$} & $\left|\begin{array}{c}\text { Standardized } \\
\text { Coefficients }\end{array}\right|$ & \multirow[b]{2}{*}{$\mathrm{t}$} & \multirow[b]{2}{*}{ Sig. } \\
\hline \multicolumn{2}{|c|}{ Model } & B & Std. Error & Beta & & \\
\hline 1 & (Constant) & 30.609 & 7.612 & & 4.021 & .000 \\
\hline & $\begin{array}{l}\text { Penerapan } \\
\text { Electronict } \\
\text { Government }\end{array}$ & .191 & .199 & .165 & .960 & .344 \\
\hline
\end{tabular}

a. Dependent Variable: Kualitas

Pelayanan

Dari tabel diatas dapat di jelaskan persamaan regresi sebagai berikut $\mathrm{Y}=30.609+0,191 \mathrm{X}$

Koefisien Penerapan Electronict Government Terhadap Kualitas Pelayanan Publik adalah positif. Artinya semakin baik Penerapan Electronict Government maka ada kecenderungan semakin baik Kualitas Pelayanan yang dicapai. Jika Penerapan Electronict Government ditingkatkan, maka Kualitas Pelayanan akan meningkat sebesar 19,1.

Konstanta sebesar 30,609 menyatakan bahwa jika tidak ada peningkatan nilai variabel Penerapan Electronict Government, maka nilai Kualitas Pelayanan sebesar 30,609.

\subsection{Koefisien Determinasi Penerapan Electronict Government Terhadap Kualitas Pelayanan Publik}

Sementara untuk mengetahui besar Pengaruh Penerapan Electronict Government Terhadap Kualitas Pelayanan Publik, maka dapat dijelaskan pada tabel berikut :

\section{Tabel 4.2}

Perhitungan Koefisien Determinasi Pengaruh Electronict Government terhadap Kualitas Pelayanan

Model Summary ${ }^{b}$

\begin{tabular}{|l|r|r|r|r|r|}
\hline Model & \multicolumn{1}{|c|}{$\mathrm{R}$} & R Square & \multicolumn{1}{c|}{$\begin{array}{c}\text { Adjusted R } \\
\text { Square }\end{array}$} & $\begin{array}{c}\text { Std. Error of } \\
\text { the Estimate }\end{array}$ & Durbin-Watson \\
\hline 1 & $.165^{\mathrm{a}}$ & .027 & -.002 & 4.280 & 1.995 \\
\hline
\end{tabular}

a. Predictors: (Constant), Penerapan Electronict Government

b. Dependent Variable: Kualitas Pelayanan

Berdasarkan analisis tabel 3.2 diatas terdapat R Square (determinasi) adalah 0,027 atau 27 persen. Untuk itu dapat dikatakan bahwa besar Pengaruh Penerapan 
Electronict Government Terhadap Kualitas Pelayanan Publik adalah sebesar 27 persen.

\subsection{Uji Hipotesis (Uji t)}

Uji t dilakukan untuk menguji hipotesis penelitian Penerapan Electronict Government terhadap variabel dependen yaitu Kualitas Pelayanan yang dapat dilihat berikut ini :

Tabel 4.3

\section{Perhitungan Uji t Pengaruh Penerapan Electronict Government Terhadap Kualitas Pelayanan Publik}

Coefficients $^{\text {a }}$

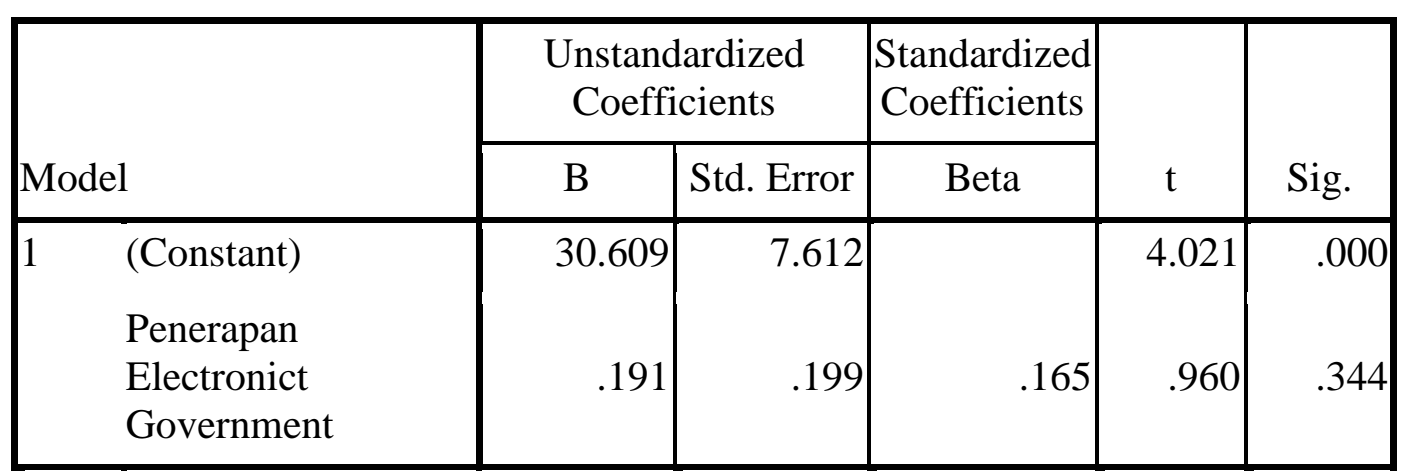

a. Dependent Variable: Kualitas

Pelayanan

Berdasarkan tabel 3.3 yaitu coefficients atau uji t ternyata didapat hasil pengujian antara variabel Penerapan Electronict Government Terhadap Kualitas Pelayanan Publik menunjukkan nilai t hitung sebesar 0,960 dengan tingkat signifikansi 0,344 >0,05\% atau thitung 0,960 < t tabel 2.733, maka Ho ditolak Ha diterima yang berarti Penerapan Electronict Government berpengaruh tidak signifikan terhadap Kualitas Pelayanan Publik.

\section{PENUTUP}

\subsection{Kesimpulan}

Berdasarkan hasil penelitian dan pembahasan tentang Pengaruh Penerapan Electronict Government Terhadap Kualitas Pelayanan Publik Pada Dinas Kependudukan dan Pencatatan Sipil Kabupaten Kerinci maka dapat diambil beberapa kesimpulan sebagai berikut :

1. Berdasarkan tabel koefisien variable Penerapan Electronict Government maka diketahui pengaruh Penerapan Electronict Government terhadap Kualitas Pelayanan yaitu 0,191. Hal ini menunjukkan bahwa Penerapan Electronict Government mempengaruhi Kualitas Pelayanan sebesar 19,1.

2. Berdasarkan tabel Sammary, dimana besar pengaruh variabel independen Penerapan Electronict Government Terhadap Kualitas Pelayanan Publik adalah dimana nilai R Square sebesar 0,027 atau 27 yang berarti bahwa besar pengaruh Penerapan Electronict Government Terhadap Kualitas Pelayanan Publik adalah 
sebesar 27 persen. Sementara sisanya sebesar 73 persen dipengaruhi faktor lain yang tidak dibahas dalam penelitian ini.

3. Berdasarkan hasil uji t variabel independen Penerapan Electronict Government Terhadap Kualitas Pelayanan Publik, dimana nilai $t$ hitung Penerapan Electronict Government sebesar 0,960 dengan tingkat signifikansi 0,344 > $0,05 \%$ atau $\mathrm{t}$ hitung $0,960<\mathrm{t}$ tabel 2.733 , maka Ho ditolak Ha diterima yang berarti Penerapan Electronict Government berpengaruh tidak signifikan terhadap Kualitas Pelayanan Publik.

\subsection{Saran}

Berdasarkan uraian kesimpulan tersebut, selanjutnya penulis memberikan saran-saran pada Dinas Kependudukan dan Pencatatan Sipil Kabupaten Kerinci.

1. Agar dapat meningkatkan Penerapan Electronict Government dalam bidang KTP-el dengan lebih baik lagi, dengan mengacu kepada tuntutan perkembangan zaman, baik secara teori maupun praktis.

2. Agar selalu memperhatikan Penerapan Electronict Government dalam bidang KTP-el yang dikerjakan oleh pegawai.

3. Disarankan, agar para pegawai dalam Penerapan Electronict Government dalam bidang KTP-el dapat meningkatkan kualitas pekerjaan agar tidak terjadi kesalahan input data.

4. Diharapkan pimpinan melakukan pengawasan terhadap pegawai dalam hal Penerapan Electronict Government dalam bidang KTP-el. 


\section{DAFTAR PUSTAKA}

Agung Kurniawan (dalam Pasalong, 2007), Teori Administrasi publik. Bandung: Alfabeta

Budi, Rianto, Tri Lestari. 2012. Polri \& Aplikasi E-Government dalam Pelayanan Publik. Surabaya : CV. Putra Media Nusantara (PMN)

Didin Parastiawan, 2017, Pengaruh Penggunaan Electronict Government Terhadap Peningkatan Kulitas Pelayanan Publik Di Kantor Pelayanan Pajak (Kpp) Pratama Samarinda, Fakultas Ilmu Sosial dan Ilmu Politik, Universitas Mulawarman

Fathoni (2006), Pemotivasian dalam Organisasi, Yudha Pustaka, Surabaya

Jackson (2006), Manajemen dan Organisasi, Reneka, Bandung

Lewis dan Gilman, (2005), Pelayanan Publik dan Organisasi, Liberty, Bandung

Marwansyah (2010), Manajemen dan Sumber Daya Manusia, Nuansa Cipta, Jakarta

Moenir. 2000. Manajemen Pelayanan Publik. Bina Aksara. Jakarta

Nawawi (2003), Cetakan ke 2, Manajemen dan Sumber Daya Manusia, Nuansa Cipta, Jakarta

Rivai (2003), Metode Penelitian Administrasi, Alfabeta, Bandung

Simamora (2000), Manajemen dan Organisasi, Putra Pustaka, Surabaya

Sastrohadiwiryo (2002), Pedoman dan Arah Organisasi, Diksi Insan Mulia, Jakarta Tjahjanto dalam Salam (2004) Manfaat Terpenting Dari Implementasi EGovernment Dalam Organisasi, Putra Jaya, Jakarta

Zheithalm et al dalam Ariani (2009), Efisensi dan Kuantitas Kerja, Citra Bangsa, Malang

Zeithaml, dan Berry dalam Saleh (2010), Kedisplinan dan Motivasi dalam Organisasi, Panca Pustaka, Jakarta

Undang-Undang Nomor 24 Tahun 2013 Tentang Perubahan Atas Undang-Undang Nomor 23 Tahun 2006 Tentang Administrasi Kependudukan

Undang-Undang Republik Indonesia. Nomor 25 tahun 2009. Tentang Pelayanan Publik

Inpres RI No.3 Tahun 2003 tentang Kebijakan dan Strategi Nasional Pengembangan e-Government

PermenPAN RB No 16 Tahun 2017 Tentang Pedoman Penyelenggaraan Forum Konsultasi Publik 